\title{
PENGARUH MEDIA PEMBELAJARAN PENGENALAN TATA CARA WUDHU DAN SHOLAT BERBASIS ANIMASI 3 DIMENSI TERHADAP HASIL BELAJAR FIQIH KELAS 1 MADRASAH IBTIDAIYAH NEGERI 1 KARANGASEM
}

\author{
Ahda Audia ${ }^{1}$, Nyoman Sugihartini ${ }^{2}$, I Made Putrama ${ }^{3}$ \\ Prodi Pendidikan Teknik Informatika \\ Jurusan Teknik Informatika \\ Universitas Pendidikan Ganesha \\ Singaaraja, Bali
}

e-mail: ahdaaudia97@gmail.com ${ }^{1}$, sugix8587@gmail.com² ${ }^{2}$ made.putrama@undiksha.ac.id ${ }^{3}$

\begin{abstract}
Abstrak- Penelitian ini bertujuan untuk mengetahui (1) perbedaan hasil belajar antara siswa yang menggunakan media pembelajaran pengenalan tata cara wudhu dan sholat berbasis animasi 3 dimensi dan siswa yang menggunakan metode ceramah (2) mengetahui respon siswa setelah menggunakan media pembelajaran pengenalan tata cara wudhu dan sholat berbasis animasi 3 dimensi. Jenis penelitian ini adalah eksperimen semu (quasi eksperimen) dengan desain Post Test Only Control Group Design. Metode pengumpulan data yang digunakan yaitu dengan metode tes pilihan ganda serta uraian untuk mengukur hasil belajar dan angket untuk untuk mengukur respon siswa. Data hasil belajar dianalisis dengan melakukan uji normalitas, uji homogenitas dan uji-t. Hasil penelitian menunjukkan bahwa rata-rata hasil analisis belajar (eksperimen > kontrol) dengan nilai kognitif $(81,46>70)$, nilai psikomotor $(95>89,23)$, nilai afektif $(79,2>70,83$. Hasil penelitian menunjukkan (1) bahwa terdapat perbedaan hasil belajar antara siswa yang belajar menggunakan media pembelajaran pengenalan tata cara wudhu dan sholat berbasis animasi 3 dimensi dan siswa yang menggunakan metode ceramah pada mata pelajaran Fiqih kelas 1 Madrasah Ibtidaiyah Negeri 1 Karangasem. (2) terdapat respon siswa dari penerapan media pembelajaran pada mata pelajara Fiqih adalah sangat positif yaitu 21 dari 25 siswa.
\end{abstract}

Kata kunci: Media Pembelajaran, Hasil Belajar Fiqih, Respon Siswa

Abstract - This study aims to determine (1) differences in learning outcomes between students who use learning media introduction to procedures for ablution and prayer based on 3-dimensional animation and students who use lecture methods (2) find out student responses after using learning media introduction to procedures for ablution and prayer based on 3-dimensional animation. This type of research is a quasi-experimental (quasi-experimental) design with Post Test Only Control Group Design. Data collection methods used are multiple choice test methods and descriptions to measure learning outcomes and questionnaires to measure student responses. Learning outcomes data were analyzed by conducting normality tests, homogeneity tests and t-tests. The results showed that the average results of the analysis of learning (experimental> control) with cognitive values (81.46> 70), psychomotor values (95> 89.23), affective values (79.2> 70.83. The results showed (1) that there are differences in learning outcomes between students who learn to use learning media introduction to procedures for ablution and prayer based on 3-dimensional animation and students who use the lecture method on class 1 Fiqh subjects Ibtidaiyah Negeri 1 Karangasem Madrasah (2) there is a student response from the application of learning media in Fiqh subjects was very positive, namely 21 out of 25 students.

Keywords : Learning Media, Fiqh Learning Results, Student Response

\section{PENDAHULUAN}

Pendidikan agama adalah hal yang terpenting untuk percaya akan ketuhanan. Pendidikan agama dimulai dari keluarga dan kemudian dilanjutkan ke TK, SD hingga tingkatan ke jenjang yang lebih tinggi. Pelaksanaan pembelajaran di keluarga belum tentu diajarkan karena faktor kesibukan para orang tua sehingga sekolah Madrasah adalah sekolah yang paling tepat untuk mendapatkan semua itu. Sebuah hasil belajar adalah perubahan tingkah laku pada seseorang, misal dari tidak tahu menjadi tahu dan tidak mengerti menjadi mengerti. Hasil belajar yang dicapai masingmasing siswa berbeda-beda tergantung dari kondisi siswa selama mengikuti proses pembelajaran. Untuk mewujudkan capaian tersebut salah satu cara yang bisa 
dilakukan oleh seorang guru adalah dengan melaksanakan pembelajaran yang inovatif. Dari hasil wawancara yang telah dilakukan dengan Guru mata pelajaran Fiqih yaitu Ibu Endang Etti Yayanti untuk hasil belajar siswa khususnya mata pelajaran Fiqih yakni kurangnya pemahaman mengenai tata cara wudhu, tata cara shalat, gerakan shalat seperti takbiratul ikhram yang benar, gerakan duduk di antara dua sujud, gerakan takbiratul ikram, gerakan tahiyad dan lafal bacaan salat. , hal tersebut dapat dilihat dari nilai ulangan akhir semester ganjil yang dicapai siswa kelas 1 Tahun Pelajaran 2017/2018, dengan jumlah siswa sebanyak 95 yang dibagi berdasarkan 4 kelas. Persentase ketuntasan nilai ulangan akhir semester ganjil pada mata pelajaran Fiqih dari perolehan nilai siswa yang mencapai KKM sebanyak 38 orang dengan tingkat persentase sebanyak $40 \%$. Selama ini proses pembelajaran yang dilaksanakan pada kelas tersebut hanya menggunakan fasilitas seperti buku paket pendeksatan saintifik kurikulum 2013 dengan menggunakan metode ceramah. Fasilitas lain yang telah disediakan disekolah yaitu LCD Proyektor, akan tetapi masih belum digunakan untuk melakukan pembelajaran di kelas tersebut. Berdasarkan uraian tersebut peneliti memberikan suatu metode yang tepat untuk penyampaian informasi kepada siswa. Salah satunya menggunakan metode demonstrasi. Metode demonstrasi adalah cara penyajian pelajaran dengan meragakan atau mempertunjukkan kepada siswa suatu proses, situasi, atau benda tertentu yang sedang dipelajari, baik sebenarnya ataupun tiruan yang sering disertai dengan penjelasan lisan. Dalam penelitian ini metode demonstrasi dikombinasikan dengan media video animasi berbasis animasi 3 Dimensi yang dapat membantu suasana belajar yang tidak menarik menjadi lebih menarik serta dapat meningkatkan minat siswa dalam pelaksanaan pembelajaan berlangsung. Dalam media tersebut sudah dilengkapi dengan audio visual, audio gambar dan audio teks yang dapat memperjelas isi dari media tersebut dan dapat mempermudah siswa untuk melakukan demonstrasi nantinya sebuah penelitian dengan judul "Pengaruh Media Pembelajaran Pengenalan Tata Cara Wudhu Dan Sholat Berbasis Animasi 3 Dimensi Terhadap Hasil Belajar Fiqih Kelas 1 Madrasah Ibtidaiyah Negeri 1 Karangasem" Berdasarkan penelitian mengenai media dan model pembelajaran terdapat beberapa penelitian terdahulu yang relevan dengan penelitian ini diantaranya (Julfaisal et al, 2018) mengembangkan sebuah media animasi 3 Dimensi dengan judul "Pengembangan Media Pembelajaran Pengenalan Tata Cara Berwudhu Dan Sholat Kepada Tk Dan Sd Berbasis Animation animasi 3 Dimensi". Latar belakang penelitian ini yaitu animasi pembelajaran tata cara Wudhu dan Sholat merupakan media yang dibutuhkan dalam pembelajaran sholat, Buku merupakan salah satu media yang digunakan untuk menunjang pembelajaran tata cara Wudhu dan Sholat, namun media seperti buku memiliki beberapa kekurangan seperti fisik yang mudah rusak, dan kurang interaktif yang menyebabkan mudah bosan sehingga diperlukan sebuah media pembelajaran yang dapat meningkatkan minat belajar pada masyarakat khususnya anak-anak.

tujuan penelitian yang ingin dicapai adalah (1)Untuk mengetahui perbedaan hasil belajar antara siswa yang menggunakan media pembelajaran pengenalan tata cara wudhu dan sholat berbasis animasi 3 Dimensi dan siswa yang menggunakan metode ceramah. (2)Untuk mengetahui respon siswa setelah menggunakan media pembelajaran pengenalan tata cara wudhu dan sholat berbasis animasi 3 Dimensi.

\section{KAJIAN TEORI}

A. Media Pembelajaran

Media pembelajaran adalah alat bantu proses belajar mengajar. Segala sesuatu yang dapat dipergunakan untuk memusatkan pikiran, perasaan, perhatian, kemampuan atau ketrampilan sehingga dapat mencapai suatu tujuan pendidikan. Media Pembelajaran adalah segala sesuatu yang digunakan untuk menyalurkan informasi dari pengirim pesan (guru) ke penerima pesan (siswa), sehingga merangsang siswa untuk berpikir dan memperhatikan proses pembelajaran agar proses belajar dapat terjadi.

\section{B. Metode Pembelajaran}

metode pembelajaran adalah cara yang digunakan guru dalam mengadakan hubungan dengan siswa pada saat pembelajaran berlangsung. Dalam kegiatan belajar mengajar dibutuhkan suatu metode pembelajaran yang menarik agar siswa tidak merasa bosan dengan materi yang diajarkan guru dan untuk mengoptimalkan proses belajar mengajar demi mencapai tujuan pembelajaran yang diharapkan. Metode mengajar yang diterapkan dalam suatu pengajaran dikatakan efektif bila menghasilkan sesuatu sesuai dengan yang diharapkan atau dapat dikatakan tujuan telah tercapai, bila semakin tinggi kekuatannya untuk menghasilkan sesuatu semakin efektif pula metode tersebut. Sedangkan metode mengajar dikatakan efisien jika penerapannya dalam menghasilkan sesuatu yang diharapkan itu relatif menggunakan tenaga, usaha pengeluaran biaya, dan waktu minimum, semakin kecil tenaga, usaha, biaya, dan waktu yang dikeluarkan maka semakin efisien metode itu. Metode atau cara yang diharapkan dapat terlaksana dengan baik, jika materi yang diajarkan dirancang telebih dahulu. Dengan kata lain bahwa untuk menerapkan suatu metode atau cara dalam pembelajaran matematika sebelumnya harus menyusun strategi belajar mengajar, dan akhirnya dapat dipilih alat peraga atau media pembelajaran sebagai pendukung materi pelajaran yang akan diajarkan

C. Wudhu 
Wudu berarti bersih dan indah. Sedangkan menurut syara' adalah bersuci dari hasdat kecil menggunakan air dengan cara membasuh bagian-bagian tertentu menurut syariat islam. Berwudhu adalah kewajiban bagi orang yang akan melakukan ibadah shalat, dan tidak sah ibadah seseorang jika di lakukan tanpa berwudhu terlebih dahulu. Allah telah menerangkan tentang wudhu dalam Qur'an (Qs.Almaidah : 6)

Wudhu sendiri dapat di lakukan di rumah atau di musholah. Wajib hukumnya bagi kaum muslim untuk berwudhu atau mensucikan diri sebelum sholat. Adapun tata cara berwudhu sebagai berikut: (1)Melakukan niat di awali dengan membaca bismillah. Dan di lanjutkan dengan membaca niat. "Sami'tu rasuulallaahi shallallaahu 'alaihi wasallama yaquulu laa wudhuu-a liman lam yadzkurismallaahi 'alaih. (2)Di lanjutkan dengan membasuh kedua telapak tangan kiri dan kanan sebanyak 3 kali. (3)Berkumur dan mengambil air di telapak tangan, kemudian ber-istinsyaq (menghirup air ke hidung dengan nafasnya secara pelan-pelan) dan beristintsar (mengeluarkan air yang telah di hirup di hidung) hal ini di lakukan sebnyak 3 kali. (4)Membasuh muka/wajah, mulai dari tempat tumbuhnya rambut sampai dagu. Dilakukan sebanyak 3 kali. (5)Membasuh kedua tangan, mulai dari ujung jari sampai ke siku-siku sebanyak 3 kali. Di mulai dari tangan kanan, baru kemudian tangan kiri. (6)Mengusap kepala mulai dari depan kepala sampai ke belakang tengkuk kepala. Di kalukan sebanyak 3 kali. (7)Di lanjutkan dengan mengusap telinga kiri dan kanan sebanyak 3 kali. (8)Membasuh kedua kaki mulai dari ujung jari kaki sampai ke mata kaki dengan menyelat-nyelat jari kaki. Di lakukan sebanyak 3 kali. (9)Membaca doa setelah wudhu. "Asy-hadu allaa illaa illallaahu wahdahuu laa syarikala, wa asyhadu anna muhammadan 'abduhu wa raasuuluh allahummaj'alnii minat tawwaabiina waj'alnii minal mutathahhiriin".

\section{Sholat}

Ibadah adalah meng- Esakan Allah SWT. Dengan sungguh-sungguh dan merendahkan serta menundukkan jiwa setunduk-tunduknya kepada-Nya. Pengertian ini didasarkan pada firman Allah SWT, dalam Al Qur"ean Surat An-Nisa"e ayat 36: "Sembahlah Allah dan janganlah kamu mempersekutukanNya dengan sesuatupun". Menurut ulama Fiqih, ibadah adalah semua bentuk pekerjaan yang bertujuan memperoleh keridhoan Allah SWT dan mendambakan pahala dari-Nya di akhirat. Ibadah merupakan rangkaian perbuatan yang disukai oleh Allah, sebab semua ibadah pada dasarnya merupakan panggilan ketakwaan. Setelah melakukan ibadah, seseorang harus menjadi lebih baik dalam hidupnya dan terhindar dari perilaku-perilaku buruk sebelumnya". Jadi manusia beribadah kepada Allah dengan mengakui bahwa tidak ada Tuhan selain Allah dan mengakui pula bahwa Muhammad adalah hamba dan Rosul-Nya. Dalam arti melaksanakan segala amal perbuatan yang terkandung dalam rukun Islam, dan melaksanakan setiap perbuatan yang dapat memperoleh keridhoan Allah dalam segala tingkah laku manusia.

E. Demonstrasi

Metode demonstrasi adalah Metode mengajar dengan cara memperagakan barang, kejadian, aturan, dan urutan melakukan suatu kegiatan, baik secara langsung maupun melalui penggunaan media pengajaran yang relevan dengan pokok bahasan atau materi yang sedang disajikan. Dengan metode demonstrasi peserta didik berkesempatan mengembangkan kemampuan mengamati segala benda yang sedang terlibat dalam proses serta dapat mengambil kesimpulan-kesimpulan yang diharapkan. Tujuan pelaksanan pembelajaran dengan menggunakan metode demonstrasi secara spisifik adalah untuk memperlihatkan proses terjadinya suatu peristiwa sesuai materi ajar, cara penyampaiannya dan kemudahan untuk dipahami oleh siswa dalam pengajaran di kelas.

\section{F. Hasil Belajar}

Hasil belajar mencakup kemampuan kognitf, afektif, dan psikomotorik. Psikomotor juga mencakup keterampilan produktif, teknik, fisik, sosial, manajerial, dan intelektual. Jadi, hasil belajar adalah prestasi belajar yang dicapai siswa dalam proses kegiatan belajar mengajar dengan membawa suatu perubahan, pembentukan tingkah laku seseorang dan hasil belajar sebagai pengukuran dari penilaian kegiatan belajar. Istilah belajar merupakan hasil dari penugasan ilmu pengetahuan yang diungkapkan dalam bentuk perubahan perilaku yang menyangkut yang harus dicapai oleh siswa selama belajar di sekolah aspek kognitif, psikomotor dan afektif.

\section{METODE}

\section{A. Jenis Penelitian}

Jenis penelitian eksperimen yang digunakan yaitu penelitian eksperimen semu (quasi eksperimen) karena pada kenyataannya tidak semua variabel dan kondisi eksperimen dapat diatur serta dikontrol secara ketat. Dikatakan sebagai ekperimen semu karena tidak semua variabel dan kondisi ekperimen dapat diatur dan kontrol secara ketat. Metode ini dilaksanakan pada kegiatan penelitian yang berlangsung dalam kondisi dimana pengontrolan variabel dirasa sulit apabila dilakukan secara 24 jam sehingga jika dilakukan ekperimen murni akan dirasa cukup sukar.

Pada penelitian ini diberikan perlakuan yang berbeda antara ke dua kelas sampel yang digunakan. Kelas pertama sebagai kelas ekperimen akan diberikan perlakuan berupa media pembelajaran video tata cara wudhu dan sholat berbasis animasi 3 Dimensi pada mata pelajaran Fiqih, sedangkan kelas kedua sebagai kelas kontrol akan diberikan perlakuan berupa penggunaan 
ISSN 2252-9063

Kumpulan Artikel Mahasiswa Pendidikan Teknik Informatika

(KARMAPATI)

Volume 8 Nomor 2, Tahun 2019

bahan ajar konvensional yakni tanpa menggunakan media pembelajaran video tata cara wudhu dan sholat berbasis animasi 3 Dimensi pada mata pelajaran Fiqih

\section{B. Desain Penelitian}

Desain penelitian yang digunakan adalah post-test only control group design. desain ini dipilih karena peneliti hanya ingin mengukur hasil belajar siswa. Berikut merupakan desain penelitian yang terdapat pada tabel 01

Tabel 01. Desain Penelitian

\begin{tabular}{|l|c|c|}
\hline Kelas & Treatment & Post-Test \\
\hline Eksperimen & $\mathrm{X}$ & $O^{1}$ \\
\hline Kontrol & - & $O^{2}$ \\
\hline
\end{tabular}

setelah diberikannya perlakuan pada tabel 01 . Design eksperimen tersebut ditunjukkan pada gambar berikut.

$O^{1}, O^{2}:$ Post-test yaitu pemberian tes sesudah perlakuan

$\mathrm{X}$ : Perlakuan bahan ajar menggunakan media pembelajaran video animasi 3 Dimensi

- : Perlakuan pada kelas kontrol yaitu media pembelajaran bersumber dari guru (konvensional)

\section{Sampel}

Teknik pengambilan sampel dalam penelitian ini yaitu dengan cara random sampling dan yang dirandom adalah kelas. Cara ini dipilih karena sulit mengubah kelas yang sudah terbentuk. Kelas dipilih sebagaimana telah terbentuk tanpa campur tangan peneliti sehingga kemungkinan pengaruh-pengaruh dari keadaan subjek engetahui dirinya dilibatkan dalam eksperimen dapat dikurangi sehingga penelitian ini benar-benar menggambarkan pengaruh perlakuan yang diberikan. Berdasarkan hasil pengundian dengan teknik simple random sampling dengan Uji ANAVA satu jalur (uji F). Syarat untuk bisa melakukan uji kesetaraan terlebih dahulu dilakukan uji normalitas sebaran data dan uji homogenitas varian. Untuk mengetahui normalitas dapat digunakan skor signifikansi yang ada pada hasil penghitungan chi-square. Bila angka signifikansi lebih besar atau sama dengan 0,05 , maka berdistribusi normal, tetapi apabila kurang maka data tidak berdistribusi normal. Untuk penjelasan lebih lengkap tersaji dalam Tabel berikut 02

\begin{tabular}{|l|l|l|l|}
\hline \multicolumn{4}{|c}{ Chi-Square Tests } \\
\hline PearsonChi-Square & $35.692^{\mathrm{a}}$ & 30 & .218 \\
Likelihood Ratio & 38.491 & 30 & .138 \\
Linear-by-Linear & 1.046 & 1 & .306 \\
Association & & & \\
N of Valid Cases & 95 & & \\
\hline
\end{tabular}

Tabel 02. Uji Normalitas
Beradasarkan uji normalitas pada tabel 02. data menggunakan chi-square tersebut untuk variabel kelas diperoleh nilai sig sebesar 0,218>0,05 yang artinya sebaran data tersebut adalah berdistribusi normal. Setelah uji normalitas data, selanjutnya melakukan uji homogenitas untuk mengetahui apakah keempat variabel mempuyai hubungan yang linear secara signifikan atau tidak. Dari penelitian ini diperoleh hasil uji homogenitas pada tabel 03.

Tabel 03. Uji Homogenitas

Test of Homogeneity of Variances

\begin{tabular}{|l|l|l|l|}
\hline Levene Statistic & df1 & df2 & Sig. \\
\hline 3.077 & 3 & 91 & 031 \\
\hline
\end{tabular}
antar kelompok dengan menggunakan Analisis Varian ( Anova ) satu jalur, diperoleh signifikansi $=0.031<$ 0.05 , Berarti varian antar kelompok adalah tidak homogen yang berarti kelas dalam kelompok ini sangat bervariasi. Unutk pengujian ANOVA dapat dilihat pada tabel 04.

Tabel 04. Uji ANOVA

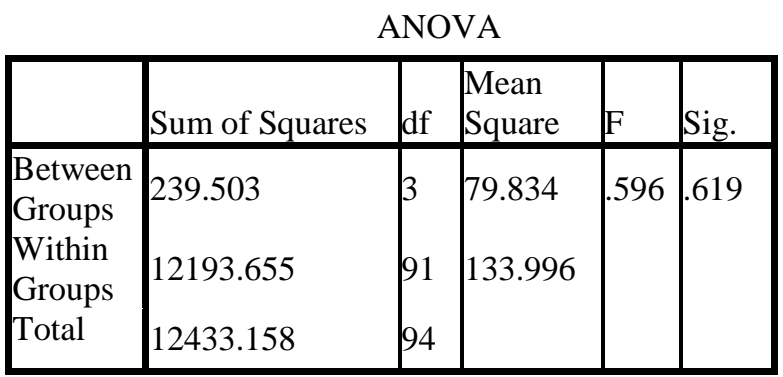

Berdasarkan hasil analisa data tabel 04 diperoleh bahwa kelas yang memiliki rata-rata paling tinggi adalah kelas $1 \mathrm{~B}$, kemudian $1 \mathrm{~A}$, lalu $1 \mathrm{C}$ dan $1 \mathrm{D}$ yang memiliki rata-rata nilai paling rendah dari yang lainnya. Berdasarkan hasil analisis, didapatkan uji anova diperoleh $\mathrm{F}$ hitung 0,596 dengan signifikansi sebesar $0,619>0,05$, maka Ho diterima dan $\mathrm{H}_{1}$ ditolak, artinya terdapat perbedaan hasil belajar untuk siswa kelas 1 MIN 1 Karangasem.

Sampel penelitian ini adalah siswa kelas 1A sebagai kelompok eksperimen ( 25 orang) dan siswa kelas 1C sebagai kelompok kontrol (24 orang) di Madrasah Ibtidaiyah Negeri 1 Karangasem.

D. Variabel Penelitian

Variabel bebas adalah variabel yang mempengaruhi atau menjadi sebab perubahan atau timbulnya variabel terikat. Variabel bebas dalam penelitian ini adalah media pembelajaran tata cara wudhu dan sholat berbasis animasi 3 Dimensi. Variabel terikat adalah variabel 
yang mempengaruhi atau diterangkan oleh variabel lain tetapi tidak dapat mempengaruhi variabel yang lain. Variabel terikat yang dalam penelitian ini adalah hasil belajar siswa kelas 1 mata pelajaran Fiqih di Madrasah Ibtidaiyah Negeri 1 Karangasem.

\section{E. Uji Coba Instrumen Penelitian}

Instrumen penelitian pada ranah kognitif diuji terlebih dahulu apakah tes hasil belajar sudah layak digunakan sebagai instrumen penelitian. Instrumen dikatakan sesuai jika instrumen tersebut sudah memenuhi kriteria Validitas dan Reliabilitas. Kualitas item khususnya dipresentasikan oleh indeks kesukaran butir dan indeks daya beda butir.

\section{F. Uji Reliabilitas}

Soal objektif

Rumus untuk uji reabilitas KR-20 sesuai dengan persamaan 01 berikut:

Persamaan 01. Rumus Uji Reliabilitas Soal Objektif

$$
r_{11}=\left(\frac{n}{n-1}\right)\left(\frac{s_{t}^{2}-n \overline{p q}}{s_{t}^{n}}\right)
$$

Keterangan Persamaan 01:

$\mathrm{r}_{11}=$ Reliabilitas Soal

$\mathrm{S}_{\mathrm{t}}=$ Standar Deviasi Skor Total

$\mathrm{n}=$ Banyak Butir

$\bar{p}=$ Proporsi rata-rata siswa yang menjawab benar untuk semua butir

$\bar{q}=$ Proporsi rata-rata siswa yang menjawab salah untuk semua butir

Soal uraian

Formula yang paling umum digunakan adalah Cronbach Alpha sesuai dengan persamaan 02 berikut:

Persamaan 02. Rumus Uji Reliabilitas Soal Uraian

$$
\mathrm{r}_{11}=\left(\frac{\mathrm{n}}{\mathrm{n}-1}\right)\left(1-\frac{\Sigma \sigma_{\mathrm{b}}^{2}}{\sigma_{\mathrm{t}}^{2}}\right)
$$

G. Uji Indeks Kesukaran Butir

Uji taraf kesukaran butir dilakukan dengan memperhitungkan banyak responden yang menjawab butir tersebut dengan benar. Oleh karena itu, validitas dan Reliabilitas tes diketahui harus dilanjuti dengan uji taraf (indeks) kesukaran butir pada persamaan 03 dan persamaan 04

$$
\begin{aligned}
& \text { Persamaan 03.Uji Indeks Kesukaran Butir Soal } \\
& \text { Objektif } \\
& \qquad \mathrm{I}=\frac{B}{J S}
\end{aligned}
$$

Keterangan :

I = Indeks Kesukaran Butir

B = Banyak Siswa yang Menjawab Butir dengan Benar
JS = Jumlah Siswa yang Mengikuti Tes

Soal Uraian

Indeks kesukaran butir untuk tes uraian dapat dihitung menggunakan rumus pada Persamaan (Candiasa, 2010)

Persamaan 04. Uji Indeks Kesukaran Butir Soal Uraian

$$
\mathrm{I}=\frac{\sum U+\sum L-(2 N * S \min )}{2 N(\mathrm{Smak}-\mathrm{Smin})}
$$

H. Uji Indeks Daya Beda Butir

Tingkat kesukaran berpengaruh langsung pada daya pembeda soal pada persamaan 05 dan 06.

Persamaan 05. Uji Indeks Daya Beda Butir Soal Objektif

Keterangan :

$$
\mathrm{DB}=\frac{B a}{J a}-\frac{B b}{J b}
$$

$\mathrm{DB}=$ Indeks daya beda tes

$\mathrm{Ba}=$ banyak kelompok atas yang menjawab butir dengan benar

$\mathrm{Ja}=$ banyak peserta kelompok atas

$\mathrm{Bb}=$ banyak kelompok bawah yang menjawab butir dengan benar

$\mathrm{Jb}=$ banyak peserta kelompok bawah

Persamaan 06. Uji Indeks Daya Beda Butir Soal

$$
\mathrm{d}=\frac{\underset{(n+1)\left(N^{2}-\sum f_{i}^{2}\right)}{n N^{2}}}{\text { Uraian }}
$$

Keterangan :

$\mathrm{d}=$ Indeks daya beda

$\mathrm{n}=$ Banyak butir

$\mathrm{f}_{\mathrm{i}}=$ Frekuensi pada tiap-tiap skor

$\mathrm{N}=$ Banyak peserta tes

\section{Menentukan Keefektifan Pengecoh}

Kriteria pengecoh yang baik adalah apabila pengecoh tersebut dipilih oleh paling sedikit 5\% dari peserta tes. Keefektifan pengecoh hanya digunakan pada post-test objektif saja, pada uraian tidak diberlakukan.

J. Teknik Analisis Data

Sebelum dilakukan uji hipotesis data yang dikumpulkan diuji prasyarat terlebih dahulu. Uji prasyarat ini dilakukan untuk membuktikan bahwa data yang dikumpulkan layak untuk dianalisis dengan statistiik parametik atau tidak. Uji prasyarat yang dilakukan adalah uji normalitas dan uji homogenitas varians.

\section{K. Uji Normalitas}

Uji normalitas data dilakukan dengan uji Chi-Square

$\left(\mathrm{X}^{2}\right)$ dengan rumus (Sugiyono, 2012) pada persamaan 07 . 
Persamaan 07. Uji Normalitas

$$
X^{2}=\sum \frac{\left(F_{0}-F_{h}\right)^{2}}{F_{h}}
$$

Keterangan :

$\mathrm{X}^{2}=$ Chi-square

$\mathrm{F}_{0}=$ frekuensi yang diperoleh sampel

$\mathrm{F}_{\mathrm{h}}=$ frekuensi yang diharapkan

Kriteria pengujian dapat berdistribusi normal jika $\mathrm{X}^{2}$ hit $<\mathrm{X}^{2}$ tab, dengan taraf signifikasi $5 \%$ dan derajat kebebasan $\mathrm{dk}=(\mathrm{k}-1)$.

\section{Uji Homogenitas}

Untuk menguji homogenitas varians untuk kedua kelompok digunakan uji-F. Adapun hipotesis yang akan diujikan yakni :

$\mathrm{H}_{0}=$ tidak ada perbedaan varians antara kelompok eksperimen (homogen) dan kelompok kontrol.

$\mathrm{H}_{1}=$ ada perbedaan varians antara kelompok kontrol dan kelompok eksperimen (tidak homogen) dengan rumus uji-F sebagai persamaan 08 berikut.

Persamaan 08. Uji Homogenitas

$$
\mathrm{F}_{\text {hit }}=\frac{S_{1}^{2}}{S_{2}^{2}}
$$

Keterangan :

$\mathrm{S}_{1}^{2}=$ varians terbesar

$\mathrm{S}_{2}^{2}=$ varians terkecil

\section{Uji Hipotesis}

Secara statistik hipotesis tersebut dapat dirumuskan sebagai berikut :

$\mathrm{H}_{0}: \mu_{1} \neq \mu_{2}$ melawan $\mathrm{H}_{1}: \mu_{1}>\mu_{2}$

Artinya adalah :

$\mathrm{H}_{0}: \mu_{1} \neq \mu_{2} \quad=$ tidak terdapat perbedaan hasil belajar antara siswa yang belajar meggunakan media pembelajaran tata cara wudhu dan sholat berbasis video animasi animasi 3 Dimensi dan siswa yang menggunakan metode ceramah mata pelajaran Fiqih kelas 1 Madrasah Ibtidaiyah Negeri 1 Karangasem.

$\mathrm{H}_{1}: \mu_{1}>\mu_{2} \quad=$ terdapat perbedaan hasil belajar antara siswa yang belajar menggunakan media pembelajaran tata cara wudhu dan sholat berbasis video animasi animasi 3 Dimensi dan siswa yang menggunakan metode ceramah pada mata pelajaran Fiqih kelas 1 Madasah Ibtidaiyah Negeri 1 Karangasem.

$\mu_{1}=$ skor rata-rata hasil belajar siswa kelas eksperimen (KE).

$\mu_{2}=$ skor rata-rata hasil belajar siswa kelas kontrol (KK).

Pengujian hipotesis menggunakan t-test terdapat beberapa rumus persamaan 09 .

Persamaan 09.Uji Hipotesis Sparated Varians.

$$
t=\frac{\overline{X_{1}}-\overline{X_{2}}}{\sqrt{\frac{s_{1}^{2}}{n_{1}}+\frac{s_{2}^{2}}{n_{2}}}}
$$

Rumus Polled Varians

$$
t=\frac{\bar{X}_{1}-\bar{X}_{2}}{\sqrt{\frac{\left(n_{1}-1\right) s_{1}{ }^{2}+\left(n_{2}-1\right) s_{2}{ }^{2}}{n_{1}+n_{2}-2}\left(\frac{1}{n_{1}}+\frac{1}{n_{2}}\right)}}
$$

Keterangan :

$\bar{X}_{1}=$ Nilai rata-rata skor kelompok eksperimen

$\bar{X}_{2}=$ Nilai rata-rata skor kelompok kontrol

$\mathrm{n}_{1}=$ banyaknya siswa kelompok eksperimen

$\mathrm{n}_{2}=$ banyaknya siswa kelompok kontrol

$\mathrm{s}_{1}^{2}=$ varians kelompok eksperimen

$\mathrm{s}_{2}{ }^{2}=$ varians kelompok kontrol

\section{N.Teknik Analisis Respon Siswa}

Angket yang digunakan adalah skala Likert dengan pilihan Sering Sekali (SS), Sering (S), Kadang-kadang (KK), Jarang (J), dan Jarang Sekali (JS), sedangkan untuk respon negatif pemberian skor terbalik dengan item positif . Untuk mencari rata-rata atau mean (M) dapat dilakukan dengan membagi jumlah semua skor $\left(\sum X\right)$ dengan jumlah siswa (n) dengan rumus persamaan 10 berikut.

Persamaan 10. Teknik Analisis Respon Siswa

$$
\mathrm{M}=\frac{\sum \mathrm{X}}{n}
$$

Keterangan :

$$
\begin{array}{ll}
\mathrm{M} & =\text { Mean atau rata-rata } \\
\sum \mathrm{X} & =\text { Jumlah skor total respon siswa } \\
\mathrm{n} & =\text { Banyaknya respon siswa }
\end{array}
$$

Untuk mencari mean ideal (MI) dan standar deviasi ideal (SDI) dapat dilakukan dengan rumus pada tabel 05 .

$\mathrm{Mi}=\frac{1}{2}($ skor maksimal ideal + skor terendah ideal $)$ Sdi $=\frac{1}{6}($ skor tertinggi ideal - skor terendah ideal $)$ Tabel 05. Pemberian Skor Respon Siswa

\begin{tabular}{|l|l|l|}
\hline \multirow{2}{*}{ Analisis Jawaban } & \multicolumn{2}{|l|}{ Nilai Item } \\
\cline { 2 - 3 } & Positif & Negatif \\
\hline SS & 5 & 1 \\
\hline S & 4 & 2 \\
\hline KS & 3 & 3 \\
\hline TS & 2 & 4 \\
\hline STS & 1 & 5 \\
\hline
\end{tabular}

\section{HASIL DAN PEMBAHASAN}

\section{A. Deskripsi Data Hasil Belajar Kelompok Eksperimen}

Data yang diperoleh dalam penelitian ini berupa hasil belajar Fiqih pada ranah kognitif, psikomotor dan afektif. tersapat 
(Kognitif)

Penilaian kognitif diperoleh dari hasil post-tes diakhir pembelajaran yang berupa soal objektif dan uraian terdapat pada tabel 06 dan 07

Tabel 06. Distribusi Frekuensi Hasil Post Test Kelompok Eksperimen

Tabel 07. Kategori Data Hasil Belajar Fiqih Kelompok Eksperimen

\begin{tabular}{|c|c|c|c|c|}
\hline Interval & $\begin{array}{l}\text { Nilai } \\
\text { Tengah }\end{array}$ & $\begin{array}{l}\text { Freku- } \\
\text { ensi } \\
\text { Obser- } \\
\text { vasi }\end{array}$ & \begin{tabular}{|l} 
Freku- \\
ensi \\
Relatif \\
$\%$
\end{tabular} & $\begin{array}{l}\text { Frekuensi } \\
\text { Komu- } \\
\text { latif \% }\end{array}$ \\
\hline $63-69$ & 66 & 3 & 12.00 & 12.00 \\
\hline $70-76$ & 73 & 4 & 16.00 & 28.00 \\
\hline $77-83$ & 80 & 9 & 36.00 & 64.00 \\
\hline $84-90$ & 87 & 4 & 16.00 & 80.00 \\
\hline $91-97$ & 94 & 4 & 16.00 & 96.00 \\
\hline 98-104 & 101 & 1 & 4.00 & 100.00 \\
\hline \multicolumn{2}{|c|}{ JUMLAH } & 25 & 100 & 380 \\
\hline
\end{tabular}

(Psikomotor)

Ranah psikomotor diperoleh dari pengamatan dikelas selama proses pembelajaran dengan menggunakan nilai berupa angka dan pada saat melakukan demonstrasi terdapat pada tabel 08 dan 09

Tabel 08. Distribusi Frekuensi Hasil Post Test Kelompok Eksperimen

Tabel 09. Kategori Data Hasil Belajar Fiqih Kelompok Eksperimen

(Afektif)

Penilaian dilakukan dengan cara bekerja sama dengan guru yang diperoleh dari pengamatan dikelas selama proses pembelajaran dengan menggunakan nilai berupa angka yang terdapat pada tabel 10 dan 11

Tabel 10. Distribusi Frekuensi Hasil Ranah Afektif Kelompok Eksperimen

\begin{tabular}{|l|l|l|l|l|}
\hline \multirow{2}{*}{ Interval } & $\begin{array}{l}\text { Nilai } \\
\text { Tengah }\end{array}$ & $\begin{array}{l}\text { Freku- } \\
\text { ensi } \\
\text { Obser- } \\
\text { vasi }\end{array}$ & $\begin{array}{l}\text { Freku- } \\
\text { ensi } \\
\text { Relatif } \\
\%\end{array}$ & $\begin{array}{l}\text { Freku- } \\
\text { ensi } \\
\text { Komu- } \\
\text { latif \% }\end{array}$ \\
\hline $75-76$ & 75.5 & 2 & 8.00 & 8.00 \\
\hline
\end{tabular}

\begin{tabular}{|l|l|l|l|l|}
\hline Interval & $\begin{array}{l}\text { Nilai } \\
\text { Tengah }\end{array}$ & $\begin{array}{l}\text { Freku- } \\
\text { ensi } \\
\text { Obser- } \\
\text { vasi }\end{array}$ & $\begin{array}{l}\text { Freku-ensi } \\
\text { Relatif \% }\end{array}$ & $\begin{array}{l}\text { Frekuensi } \\
\text { Komulatif\% }\end{array}$ \\
\hline $90-91$ & 90.5 & 1 & 4.00 & 4.00 \\
\hline $92-93$ & 92.5 & 7 & 28.00 & 32.00 \\
\hline $94-95$ & 94.5 & 5 & 20.00 & 52.00 \\
\hline $96-97$ & 96.5 & 9 & 36.00 & 88.00 \\
\hline $98-99$ & 98.5 & 2 & 8.00 & 96.00 \\
\hline $\begin{array}{l}100- \\
102\end{array}$ & 100.5 & 1 & 4.00 & 100.00 \\
\hline \multicolumn{2}{|l}{ JUMLAH } & 25 & 100 & 372 \\
\hline
\end{tabular}

\begin{tabular}{|c|c|c|c|c|}
\hline $\begin{array}{c}\text { Rentangan } \\
\text { Skor }\end{array}$ & Kategori & \multicolumn{2}{|c|}{ Frekuensi } & Persentase \\
\hline $75 \leq X \leq 100$ & $\begin{array}{l}\text { Sangat } \\
\text { Tinggi }\end{array}$ & \multicolumn{2}{|l|}{25} & 100 \\
\hline $58,33 \leq X$ & Tinggi & \multicolumn{2}{|l|}{0} & \\
\hline Reptangan & Kategori & Frekuensi & Persentase & \\
\hline Skgr1,67 $\leq x$ & Sedang & 0 & & \multirow[b]{2}{*}{0} \\
\hline $75 \approx 58,33^{100}$ & Sangat & \multirow{2}{*}{18} & & \\
\hline $25 \leq X$ & Thegdah & & & \multirow[b]{2}{*}{0} \\
\hline 5838158 & Tinggi & 7 & & \\
\hline $8 \geq 5 x<25$ & Sangat & 0 & & \\
\hline $41,67 \leq X$ & Sqreingah & 0 & & 0 \\
\hline$\Varangle 58$, spiplah & & 25 & & 100 \\
\hline $25 \leq X<41,6$ & Rendah & 0 & & 0 \\
\hline $0 \leq X<25$ & $\begin{array}{l}\text { Sangat } \\
\text { Rendah }\end{array}$ & 0 & & 0 \\
\hline Jumlah & & 25 & & 100 \\
\hline $77-78$ & .5 & 0 & 40.00 & 48.00 \\
\hline $79-80$ & .5 & & 32.00 & 80.00 \\
\hline $81-82$ & .5 & & 12.00 & 92.00 \\
\hline $83-84$ & .5 & & 8.00 & 100.00 \\
\hline $85-86$ & .5 & & 0.00 & 100.00 \\
\hline JUMLAH & & 5 & 100 & 428 \\
\hline
\end{tabular}

Tabel 11. Kategori Data Hasil Belajar Fiqih Kelompok Eksperimen

\begin{tabular}{|l|l|l|l|}
\hline $\begin{array}{l}\text { Rentangan } \\
\text { Skor }\end{array}$ & Kategori & Frekuensi & Persentase \\
\hline $75 \leq X \leq 100$ & $\begin{array}{l}\text { Sangat } \\
\text { Tinggi }\end{array}$ & 25 & 100 \\
\hline $\begin{array}{l}58,33 \leq X \\
<75\end{array}$ & Tinggi & 0 & 0 \\
\hline $\begin{array}{l}41,67 \leq X \\
<58,33\end{array}$ & Sedang & 0 & 0 \\
\hline $\begin{array}{l}25 \leq X \\
<41,67\end{array}$ & Rendah & 0 & 0 \\
\hline $0 \leq X<25$ & $\begin{array}{l}\text { Sangat } \\
\text { Rendah }\end{array}$ & 0 & 0 \\
\hline Jumlah & & 25 & 100 \\
\hline
\end{tabular}

\section{B. Deskripsi Data Hasil Belajar Kelompok Kontrol}

Deskriptif hasil belajar kontrol ranah kognitif terdapat pada tabel 12 dan 13

(Kognitif)

Tabel 12. Distribusi Frekuensi Hasil Ranah Kognitif Kelompok Kontrol

\begin{tabular}{|l|l|l|l|l|}
\hline Interval & $\begin{array}{l}\text { Nilai } \\
\text { Tengah }\end{array}$ & $\begin{array}{l}\text { Freku- } \\
\text { ensi }\end{array}$ & $\begin{array}{l}\text { Freku- } \\
\text { ensi }\end{array}$ & $\begin{array}{l}\text { Freku- } \\
\text { ensi }\end{array}$ \\
\hline
\end{tabular}


ISSN 2252-9063

Kumpulan Artikel Mahasiswa Pendidikan Teknik Informatika

(KARMAPATI)

Volume 8 Nomor 2, Tahun 2019

\begin{tabular}{|l|l|l|l|l|}
\hline & & $\begin{array}{l}\text { Obser- } \\
\text { vasi }\end{array}$ & $\begin{array}{l}\text { Relatif } \\
\%\end{array}$ & $\begin{array}{l}\text { Komu- } \\
\text { latif \% }\end{array}$ \\
\hline $53-58$ & 55.5 & 3 & 12.50 & 12.50 \\
\hline $59-64$ & 61.5 & 5 & 20.83 & 33.33 \\
\hline $65-70$ & 67.5 & 6 & 25.00 & 58.33 \\
\hline $71-76$ & 73.5 & 1 & 4.17 & 62.50 \\
\hline $77-82$ & 79.5 & 6 & 25.00 & 87.50 \\
\hline $83-88$ & 85.5 & 3 & 12.50 & 100.00 \\
\hline JUMLAH & 24 & 100 & 354.17 \\
\hline
\end{tabular}

Tabel 13. Kategori Data Hasil Belajar Fiqih Kelompok Kontrol

\begin{tabular}{|l|l|l|l|}
\hline $\begin{array}{l}\text { Rentangan } \\
\text { Skor }\end{array}$ & Kategori & Frekuensi & $\begin{array}{l}\text { Persenta } \\
\text { se }\end{array}$ \\
\hline $\begin{array}{c}75 \leq X \\
\leq 100\end{array}$ & $\begin{array}{l}\text { Sangat } \\
\text { Tinggi }\end{array}$ & 9 & 37.50 \\
\hline $\begin{array}{c}58,33 \leq X \\
<75\end{array}$ & Tinggi & 12 & 50 \\
\hline $\begin{array}{c}41,67 \leq X \\
<58,33\end{array}$ & Sedang & 3 & 12.50 \\
\hline $\begin{array}{c}25 \leq X \\
<41,67\end{array}$ & Rendah & 0 & 0 \\
\hline $\begin{array}{c}0 \leq X<25 \\
<\end{array}$ & $\begin{array}{l}\text { Sangat } \\
\text { Rendah }\end{array}$ & 0 & 0 \\
\hline Jumlah & & 24 & 100 \\
\hline
\end{tabular}

(Psikomotor)

Deskriptif hasil belajar kontrol ranah psikomotor terdapat pada tabel 14 dan 15

Tabel 14. Distribusi Frekuensi Hasil Ranah Psikomotor Kelompok Kontrol

\begin{tabular}{|l|l|l|l|l|}
\hline Interval & $\begin{array}{l}\text { Nilai } \\
\text { Tengah }\end{array}$ & $\begin{array}{l}\text { Freku- } \\
\text { ensi } \\
\text { Obser- } \\
\text { vasi }\end{array}$ & $\begin{array}{l}\text { Freku- } \\
\text { ensi } \\
\text { Relatif } \\
\%\end{array}$ & $\begin{array}{l}\text { Freku- } \\
\text { ensi } \\
\text { Komu- } \\
\text { latif \% }\end{array}$ \\
\hline $84-85$ & 84.5 & 1 & 4.17 & 4.17 \\
\hline $86-87$ & 86.5 & 7 & 29.17 & 33.33 \\
\hline $88-89$ & 88.5 & 5 & 20.83 & 54.17 \\
\hline $90-91$ & 90.5 & 6 & 25.00 & 79.17 \\
\hline $92-93$ & 92.5 & 5 & 20.83 & 100.00 \\
\hline $94-95$ & 94.5 & 0 & 0.00 & 100.00 \\
\hline JUMLAH & & 24 & 100 & 370.83 \\
\hline
\end{tabular}

Tabel 15. Kategori Data Hasil Belajar Fiqih Kelompok Kontrol

\begin{tabular}{|l|l|l|l|}
\hline $\begin{array}{l}\text { Rentangan } \\
\text { Skor }\end{array}$ & Kategori & $\begin{array}{l}\text { Frekuen } \\
\text { si }\end{array}$ & Persentase \\
\hline $\begin{array}{l}75 \leq X \\
\leq 100\end{array}$ & $\begin{array}{l}\text { Sangat } \\
\text { Tinggi }\end{array}$ & 24 & 100 \\
\hline $\begin{array}{l}58,33 \leq X \\
<75\end{array}$ & Tinggi & 0 & 0 \\
\hline
\end{tabular}


ISSN 2252-9063

Kumpulan Artikel Mahasiswa Pendidikan Teknik Informatika

(KARMAPATI)

Volume 8 Nomor 2, Tahun 2019

Tests of Normality

\begin{tabular}{|c|c|c|c|c|c|c|c|}
\hline \multirow{4}{*}{$\begin{array}{l}\text { NILAI } \\
\text { KOG } \\
\text { NITIF }\end{array}$} & \multirow{2}{*}{$\begin{array}{l}\text { KELO } \\
\text { MPOK }\end{array}$} & \multicolumn{3}{|c|}{$\begin{array}{l}\text { Kolmogorov- } \\
\text { Smirnova }^{\mathrm{a}}\end{array}$} & \multicolumn{3}{|c|}{ Shapiro-Wilk } \\
\hline & & $\begin{array}{l}\text { Statisti } \\
\mathrm{c}\end{array}$ & df & Sig. & $\begin{array}{l}\text { Statis } \\
\text { tic }\end{array}$ & df & Sig. \\
\hline & $\begin{array}{l}\text { EKSPE } \\
\text { RIMEN }\end{array}$ & .117 & 25 & $.200^{*}$ & .970 & 25 & .634 \\
\hline & $\begin{array}{l}\text { KONT } \\
\text { ROL }\end{array}$ & .137 & 24 & $.200^{*}$ & .958 & 24 & .402 \\
\hline
\end{tabular}

Dari gambar di atas perhatikan Kolom Sig. pada Uji Shapiro-Wilk terlihat bahwa nilai probabilitasnya (nilai Sig. atau p) untuk kelas eksperimen $=0,634$ dan kontrol $=0,402$ yang semua lebih dari $\alpha=0,05$ sehingga sebaran data kelas kontrol dan eksperimen berdistribusi Normal. (Sama untuk Kolmogorov-Smirnov semua sig. di atas 0,05$)$

(Ranah Psikomotor)

Tabel 19. Uji Normalitas Psikomotor

\begin{tabular}{|c|c|c|c|c|c|c|c|}
\hline \multicolumn{8}{|c|}{ Tests of Normality } \\
\hline \multirow{4}{*}{$\begin{array}{l}\text { NILAI } \\
\text { PSIKO } \\
\text { MOTOR }\end{array}$} & \multirow[b]{2}{*}{$\begin{array}{l}\text { KELO- } \\
\text { MPOK }\end{array}$} & \multicolumn{3}{|c|}{$\begin{array}{l}\text { Kolmogorov- } \\
\text { Smirnov }^{\mathrm{a}}\end{array}$} & \multicolumn{3}{|c|}{ Shapiro-Wilk } \\
\hline & & $\begin{array}{l}\text { Statis } \\
\text { tic }\end{array}$ & df & Sig. & $\begin{array}{l}\text { Statis } \\
\text { tic }\end{array}$ & df & Sig. \\
\hline & $\begin{array}{l}\text { EKSEPE } \\
\text { RIMEN }\end{array}$ & .123 & 25 & $.200^{*}$ & .971 & 25 & .676 \\
\hline & $\begin{array}{l}\text { KONTR } \\
\text { OL }\end{array}$ & .142 & 24 & $.200^{*}$ & .961 & 24 & .456 \\
\hline
\end{tabular}

Kolom Sig. pada Uji Shapiro-Wilk terlihat bahwa nilai probabilitasnya (nilai Sig. atau p) untuk kelas eksperimen $=0,676$ dan kontrol $=0,456$ yang semua lebih dari $\alpha=0,05$ (normal)

(Afektif)

Tabel 20. Uji Normalitas Afektif

\begin{tabular}{|l|l|l|l|l|l|l|l|}
\hline \multicolumn{3}{|l|}{ Tests of Normality } \\
\hline \multirow{3}{*}{$\begin{array}{l}\text { NILAI } \\
\text { AFEKT } \\
\text { IF }\end{array}$} & $\begin{array}{l}\text { KELOM } \\
\text { POK }\end{array}$ & $\begin{array}{l}\text { Kolmogorov- } \\
\text { Smirnova }\end{array}$ & $\begin{array}{l}\text { Statis } \\
\text { tic }\end{array}$ & df & Sig. & \multicolumn{3}{|l|}{$\begin{array}{l}\text { Statis } \\
\text { tic }\end{array}$} & df & Sig. \\
\cline { 2 - 9 } & $\begin{array}{l}\text { EKSPER } \\
\text { IMEN }\end{array}$ & .161 & 25 & .093 & .943 & 25 & .173 \\
\cline { 2 - 9 } & $\begin{array}{l}\text { KONTR } \\
\text { OL }\end{array}$ & .169 & 24 & .074 & .941 & 24 & .173 \\
\hline
\end{tabular}

Kolom Sig. pada Uji Shapiro-Wilk terlihat bahwa nilai probabilitasnya (nilai Sig. atau p) untuk kelas eksperimen $=0,173$ dan kontrol $=0,173$ yang semua lebih dari $\alpha=0,05$ (normal).

Uji Homogenitas

taraf signifikan 0,05 . Kreteria pengujiannya apabila nilai signifikasi yang dihasilkan lebih besar dari 0,05 , maka dapat dikatakan homogeny, demikian juga sebaliknya. Hal tersebut dapat dilihat pada tabel 21, 22 dan 23

(Kognitif)

Tabel 21. Uji Homogenitas Kognitif

\begin{tabular}{|c|c|c|c|c|c|}
\hline \multicolumn{6}{|c|}{ Test of Homogeneity of Variance } \\
\hline & & $\begin{array}{l}\text { Levene } \\
\text { Statistic }\end{array}$ & df1 & df2 & Sig. \\
\hline \multirow{4}{*}{$\begin{array}{l}\text { NILAI } \\
\text { KOGNI } \\
\text { TIF }\end{array}$} & $\begin{array}{l}\text { Based on } \\
\text { Mean }\end{array}$ & .028 & 1 & 47 & .868 \\
\hline & $\begin{array}{ll}\text { Based } & \text { on } \\
\text { Median } & \\
\end{array}$ & .002 & 1 & 47 & .962 \\
\hline & $\begin{array}{|lr|}\text { Based r on } \\
\text { Median and } \\
\text { with } \\
\text { adjusted df }\end{array}$ & .002 & 1 & $\begin{array}{l}45.4 \\
11\end{array}$ & .962 \\
\hline & $\begin{array}{ll}\text { Based on } \\
\text { trimmed } \\
\text { mean }\end{array}$ & .028 & 1 & 47 & .869 \\
\hline
\end{tabular}

uji homogenitas varians menunjukan nilai Sig. (probabilitas) sebesar 0,868 (lihat Based on Mean). Nilai ini lebih dari 0,05 (homogen/setara).

(Psikomotor)

Tabel 22. Uji Homogenitas Psikomotor

\begin{tabular}{|c|c|c|c|c|c|}
\hline & & \begin{tabular}{|l|} 
Levene \\
Statistic
\end{tabular} & df1 & df2 & Sig. \\
\hline \multirow{4}{*}{$\begin{array}{l}\text { NILAI } \\
\text { PSIKO } \\
\text { MOTO } \\
\mathrm{R}\end{array}$} & Based on Mean & .158 & 1 & 47 & .693 \\
\hline & $\begin{array}{ll}\text { Based } & \text { on } \\
\text { Median } & \end{array}$ & .144 & 1 & 47 & .706 \\
\hline & $\begin{array}{lr}\text { Based } & \text { on } \\
\text { Median } & \text { and } \\
\text { with adjusted df }\end{array}$ & .144 & 1 & $\begin{array}{l}46.2 \\
28\end{array}$ & .706 \\
\hline & $\begin{array}{l}\text { Based on } \\
\text { trimmed mean }\end{array}$ & .152 & 1 & 47 & .699 \\
\hline
\end{tabular}

uji homogenitas varians menunjukan nilai Sig. (probabilitas) sebesar 0,693 (lihat Based on Mean). Nilai ini lebih dari 0,05 sehingga dapat disimpulkan bahwa variasi kelas kontrol dan eksperimen Setara (Homogen).

(Afektif) 
Tabel 23. Uji Homogenitas Afektif

\begin{tabular}{|l|l|l|l|l|l|l|}
\hline \multicolumn{7}{|l|}{ Test of Homogeneity of Variance } \\
\hline & \multicolumn{1}{|l|}{$\begin{array}{l}\text { Levene } \\
\text { Statistic }\end{array}$} & df1 & df2 & Sig. \\
\hline $\begin{array}{l}\text { NILAI } \\
\text { AFEK } \\
\text { TIF }\end{array}$ & $\begin{array}{l}\text { Based on } \\
\text { Mean }\end{array}$ & $\begin{array}{l}\text { Based on } \\
\text { Median }\end{array}$ & .287 & 1 & 47 & .489 \\
\cline { 2 - 7 } & $\begin{array}{l}\text { Based on } \\
\text { Median } \\
\text { and with } \\
\text { adjusted df }\end{array}$ & .284 & 1 & 42.126 & .597 \\
\cline { 2 - 6 } & $\begin{array}{l}\text { Based on } \\
\text { trimmed } \\
\text { mean }\end{array}$ & .486 & 1 & 47 & .596 \\
\hline
\end{tabular}

uji homogenitas varians menunjukan nilai Sig. (probabilitas) sebesar 0,489 (lihat Based on Mean). Nilai ini lebih dari 0,05 bahwa variasi kelas kontrol dan eksperimen Setara (Homogen).

Uji Hipotesis

Uji hipotesis dilakukan dengan menggunkan Uji $\mathrm{t}$ dengan menggunakan program SPSS 16.0 pada taraf signifikan 0,05 . Hal tersebut terdapat pada tabel 24,25 dan 26

(Kognitif)

\begin{tabular}{|c|c|c|c|c|c|c|c|c|c|}
\hline \multicolumn{10}{|c|}{ Independent Samples Test } \\
\hline \multicolumn{10}{|c|}{ t-test for Equality of Means } \\
\hline \multirow{2}{*}{$\begin{array}{l}\text { NILAI } \\
\text { KOGNI } \\
\text { TIF }\end{array}$} & \multirow[b]{2}{*}{$\mathrm{F}$} & \multirow[b]{2}{*}{ Sig } & \multirow[b]{2}{*}{$\mathrm{t}$} & \multirow[b]{2}{*}{ df } & \multirow{2}{*}{\begin{tabular}{|c|} 
Sig. \\
$(2-$ \\
taile \\
d)
\end{tabular}} & \multirow[b]{2}{*}{$\begin{array}{l}\text { Mean } \\
\text { Diffe } \\
\text { rence }\end{array}$} & \multirow{2}{*}{$\begin{array}{l}\text { Std. } \\
\text { Error } \\
\text { Diffe } \\
\text { rence }\end{array}$} & \multirow[b]{2}{*}{$\begin{array}{l}\text { Lo } \\
\text { wer }\end{array}$} & \multirow[b]{2}{*}{$\begin{array}{l}\text { Up } \\
\text { per }\end{array}$} \\
\hline & & & & & & & & & \\
\hline $\begin{array}{l}\text { Equal } \\
\text { variance } \\
\text { s } \\
\text { assumed }\end{array}$ & $\begin{array}{r}.0 \\
28\end{array}$ & $\begin{array}{r}.86 \\
8\end{array}$ & $\begin{array}{r}4.0 \\
55\end{array}$ & 47 & .000 & $\begin{array}{r}11.46 \\
667\end{array}$ & $\begin{array}{r}2.827 \\
72\end{array}$ & $\begin{array}{r}5.7 \\
780 \\
3\end{array}$ & $\begin{array}{r}17 . \\
155 \\
30\end{array}$ \\
\hline $\begin{array}{l}\text { Equal } \\
\text { variance } \\
\text { s not } \\
\text { assumed }\end{array}$ & & & $\begin{array}{r}4.0 \\
61\end{array}$ & $\begin{array}{r}46 . \\
959\end{array}$ & .000 & $\begin{array}{r}11.46 \\
667\end{array}$ & $\begin{array}{r}2.823 \\
54\end{array}$ & $\begin{array}{r}5.7 \\
863 \\
1\end{array}$ & $\begin{array}{r}17 . \\
147 \\
02\end{array}$ \\
\hline
\end{tabular}

Nilai $\mathrm{t}$ hitung menunjukan nilai 4,055 dan t tabel dengan $\frac{\alpha}{2}=0,025$ dan $\mathrm{df}=47$ adalah 2,31548, |t hitung $>$ t tabel $\mid(4,055$ > 2,31548) maka H0 Ditolak.

(Psikomotor)

Tabel 25. Uji Hipotesis Psikomotor

\begin{tabular}{|c|c|c|c|c|c|c|c|c|c|}
\hline \multicolumn{10}{|c|}{ Independent Samples Test } \\
\hline \multicolumn{10}{|c|}{ t-test for Equality of Means } \\
\hline \multirow{2}{*}{$\begin{array}{l}\text { NILAI } \\
\text { PSIKOM } \\
\text { OTOR }\end{array}$} & \multirow[b]{2}{*}{$\mathrm{F}$} & \multirow[b]{2}{*}{ Sig } & \multirow[b]{2}{*}{$\mathrm{t}$} & \multirow[b]{2}{*}{$\mathrm{df}$} & \multirow[b]{2}{*}{$\begin{array}{l}\text { Sig. } \\
(2- \\
\text { taile } \\
\text { d) }\end{array}$} & \multirow[b]{2}{*}{$\begin{array}{l}\text { Mean } \\
\text { Diffe } \\
\text { ren- } \\
\text { ce }\end{array}$} & \multirow[b]{2}{*}{\begin{tabular}{|l} 
Std. \\
Erro \\
$\mathrm{r}$ \\
Diff \\
eren \\
ce
\end{tabular}} & \multirow[b]{2}{*}{$\begin{array}{l}\text { Lo } \\
\text { wer }\end{array}$} & \multirow[b]{2}{*}{$\begin{array}{l}\text { Upp } \\
\text { er }\end{array}$} \\
\hline & & & & & & & & & \\
\hline $\begin{array}{l}\text { Equal } \\
\text { variances } \\
\text { assumed }\end{array}$ & $\begin{array}{l}.1 \\
58\end{array}$ & $\begin{array}{l}.69 \\
3\end{array}$ & $\begin{array}{l}8 . \\
85 \\
2\end{array}$ & 47 & .000 & $\begin{array}{l}5.763 \\
89\end{array}$ & $\begin{array}{l}.651 \\
16\end{array}$ & \begin{tabular}{|l|}
4.4 \\
539 \\
3
\end{tabular} & $\begin{array}{l}7.07 \\
385\end{array}$ \\
\hline $\begin{array}{l}\text { Equal } \\
\text { variances } \\
\text { not } \\
\text { assumed }\end{array}$ & & & $\begin{array}{l}8 . \\
86 \\
8\end{array}$ & $\begin{array}{l}46 . \\
909\end{array}$ & .000 & $\begin{array}{l}5.763 \\
89\end{array}$ & $\begin{array}{l}.650 \\
00\end{array}$ & \begin{tabular}{|l|}
4.4 \\
562 \\
0
\end{tabular} & $\begin{array}{l}7.07 \\
158\end{array}$ \\
\hline
\end{tabular}

Nilai $\mathrm{t}$ hitung menunjukan nilai 8,852 dan $\mathrm{t}$ tabel dengan $\frac{\propto}{2}=0,025 \mathrm{dan} \mathrm{df}=47$ adalah 2,31548, |t hitung| $>$ t tabel $\mid(8,852>2,31548)$ maka H0 Ditolak.

(Afektif)

Tabel 26. Uji Hipotesis Afektif

\begin{tabular}{|c|c|c|c|c|c|c|c|c|c|}
\hline \multicolumn{10}{|c|}{ Independent Samples Test } \\
\hline \multicolumn{10}{|c|}{ t-test for Equality of Means } \\
\hline \multirow{2}{*}{$\begin{array}{l}\text { NILAI } \\
\text { AFEKTIF }\end{array}$} & & & & & & & Std. & & \\
\hline & $\mathrm{F}$ & Sig & $\mathrm{t}$ & df & $\begin{array}{l}\text { Sig. } \\
(2- \\
\text { taile } \\
\text { d) }\end{array}$ & $\begin{array}{l}\text { Mean } \\
\text { Diffe } \\
\text { ren- } \\
\text { ce }\end{array}$ & \begin{tabular}{|l} 
Erro \\
$\mathrm{r}$ \\
Diff \\
ere- \\
nce
\end{tabular} & $\begin{array}{l}\text { Low } \\
\text { er }\end{array}$ & $\begin{array}{l}\text { Upp } \\
\text { er }\end{array}$ \\
\hline $\begin{array}{l}\text { Equal } \\
\text { variances } \\
\text { assumed }\end{array}$ & \begin{tabular}{|l}
.4 \\
87
\end{tabular} & $\begin{array}{l}.48 \\
9\end{array}$ & $\begin{array}{l}14 \\
.1 \\
69\end{array}$ & 47 & .000 & $\begin{array}{l}8.366 \\
67\end{array}$ & $\begin{array}{l}.590 \\
49\end{array}$ & $\begin{array}{l}7.17 \\
876\end{array}$ & $\begin{array}{l}9.55 \\
458\end{array}$ \\
\hline $\begin{array}{l}\text { Equal } \\
\text { variances } \\
\text { not } \\
\text { assumed }\end{array}$ & & & $\begin{array}{l}14 \\
.2 \\
13\end{array}$ & $\begin{array}{l}46 \\
.4 \\
64\end{array}$ & .000 & $\begin{array}{l}8.366 \\
67\end{array}$ & $\begin{array}{l}.588 \\
66\end{array}$ & $\begin{array}{l}7.18 \\
207\end{array}$ & $\begin{array}{l}9.55 \\
126\end{array}$ \\
\hline
\end{tabular}

Nilai t hitung menunjukan nilai 14,169 dan t tabel dengan $\frac{\alpha}{2}=0,025$ dan $\mathrm{df}=47$ adalah 2,31548, |t hitung| $>\mid t$ tabel $\mid(14,169$ > 2,31548) maka H0 Ditolak, atau terdapat per bedaan rata-rata kelas kontrol dan eksperimen.

Respon Siswa

Sebaran angket kuisioner diberikan di akhir perlakuan terhadap respon siswa setelah menggunakan media pembelajaran pengenalan tata cara wudhu dan sholat 
berbasis animasi 3 dimensi yang berjumlah 25 siswa. Kriteria dan sebaran skor dapat dilihat pada gambar 01 berikut.

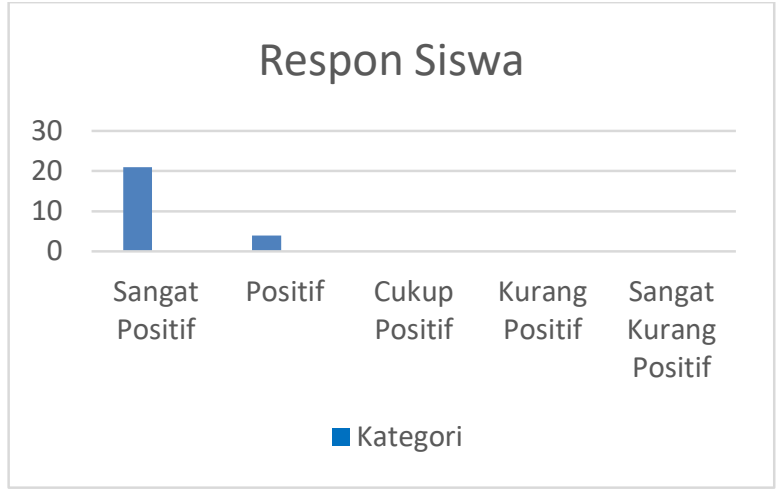

Gambar 01. Histogram Respon Siswa Berdasarkan gambar 01. Terdapat repon siswa dengan kategori sangat positif sebanyak 21 orang dari 25 siswa.

\section{PEMBAHASAN}

Hasil penelitian yang meliputi analisis deskriptif dan analisis statistik mengungkapkan bahwa terdapat pengaruh variable bebas terhadap variable terikat. Adapun variable bebas dalam penelitian ini yakni Penggunaan media pembelajaran tata cara wudhu dan sholat berbasis animasi 3 Dimensi. Sedangkan variable terikatnya adalah hasil belajar Fiqih. Adapun sampel penelitian yang digunakan yaitu kelas $1 \mathrm{~A}$ sebagai kelas eksperimen dan kelas 1C sebagai kelas kontrol yang telah diuji kesetaraannya menggunakan teknik Simple Random Sampling untuk meyakinkan bahwa kelas tersebut benar-benar setara.

Berdasarkan hasil penelitian yang telah dianalisa pada kedua kelompok belajar tersebut dapat diketahui bahwa nilai rata-rata hasil belajar kelompok eksperimen mengalami peningkatan yang cukup baik, dimana terdapat perbedaan rata-rata hasil belajar siswa (post-test) antara kelas yang menggunakan media pembelajaran $(81,46)$ lebih tinggi daripada kelas yang belajar tanpa menggunakan media pembelajaran (70). Hasil tersebut dapat dilihat dari hasil Post-test hasil belajar siswa.

Perhitungan normalitas, homogenitas dan uji hipotesis menggunakan Microsoft Excel 2013 dengan SPSS 16.0 hasilnya tidak jauh berbeda, pengujian signifikansi pada penelitian ini bertujuan untuk melihat apakah ada pengaruh penggunaan media pembelajaran pengenalan tata cara wudhu dan sholat berbasis animasi 3 dimensi yang digunakan pada kelas eksperimen untuk meningkatkan hasil belajar. Untuk melihat hasil dari analisis tersebut maka pengujian dalam penelitian ini menggunakan uji-t. Dalam Pengujian ini bertujuan untuk mengetahui apakah data yang diperoleh terdistribusi normal serta homogen, dan apakah terdapat pengaruh dalam penggunaan penggunaan media pembelajaran tersebut dengan pengujian hipotesis yang menggunakan rumus uji-t dengan taraf signifikan 0,05 .

Untuk respon siswa terhadap penggunaan media pembelajaran pengenalan tata cara wudhu dan sholat berbasis animasi 3 dimensi yang diisi oleh 25 siswa dengan 10 butir soal. Berdasarkan hal tersebut didapat skor respon siswa sangat positif sebanyak 21, kategori positif sebanyak 4, cukup positif 0 , kurang positif 0 dan sangat kurang positif 0 . Dari data tersebut dapat dikatakan bahwa penggunaan media pembelajaran pengenalan tata cara wudhu dan sholat sangat positif. Menurut peneliti hal tersebut sangat baik digunakan dan diterapkan di sekolah khususnya pada mata pelajaran Fiqih tentang pengenalan tata cara wudhu dan sholat.

\section{SIMPULAN}

Berdasarkan dari hasil penelitian dan pembahasan yang telah dipaparkan, maka dapat disimpulkan bahwa (1)Terdapat perbedaan hasil belajar antara siswa yang menggunakan media pembelajaran pengenalan tata cara wudhu dan sholat berbasis animasi 3 dimensi dengan siswa yang tanpa meggunakan media tersebut. (2)Terdapat hasil respon siswa yang menggunakan media pembelajaran pengenalan tata cara wudhu dan sholat berbasis animasi 3 dimensi dengan skor tertinggi pada kategori sangat positif sebanyak 21 dari 25 siswa. Sehingga menggunakan media pembelajaran pengenalan tata cara wudhu dan sholat berbasis animasi 3 dimensi yang dikembangkan oleh julfaisal., et al (2018) baik untuk diterapkan dalam proses pembelajaran.

\section{SARAN}

Berdasarkan hasil penelitian dapat diajukan beberapa saran guna untuk meningkatkan kualitas pembelajaran pada mata pelajaran Fiqih (1) Hasil penelitian ini menunjukkan bahwa siswa yang belajar menggunakan media pembelajaran pengenalan tata cara wudhu dan sholat berbasis animasi 3 dimensi memperoleh hasil belajar yang lebih baik daripada siswa yang hanya menggunakan media pembelajaran secara konvensional (ceramah). Oleh karena itu, penulis menyarankan kepada guru untuk mengajar menerapkan media pembelajaran pengenalan tata cara wudhu dan sholat berbasis animasi 3 dimensi pada proses pembelajaran selanjutnya. (2) Pada penelitian ini peneliti menyarankan kepada peneliti lain yang akan mengembangkan media pembelajaran animasi 3 dimensi tentang tata cara wudhu dan sholat agar menambahkan video tata cara berwudhu mengenai perbandingan mencuci kedua tangan sampai siku-suku 
dengan mencuci kedua kaki hingga ke mata kaki. Kemudian untuk di bagian tata cara sholat agar dibandingkan lafal bacaan surah al-fatihah dengan lafal takbiratul ihram. (3) Peneliti menyarankan kepada peneliti lain yang akan melakukan penelitian sejenis atau eksperimen agar bisa mengkondisikan waktu penelitian sebaik mungkin dan mengkondisikan keadaan kelas saat melaksanakan tes akhir (post-test).

\section{EFERENCES}

[1] Azwar, S. (2012). Reliabilitas Dan Validita. Yogyakarta: Pustaka Pelajar.

[2] Candiasa, I. M. (2010). Statistik Multivariat Disertai Aplikasi Spss. Singaraja: Unit Penerbit Undiksha.

[3] Imam Julfaisal et al (2018). Pengembangan Media Pembelajaran Pengenalan Tata Cara Wudhu Dan Sholat Berbasis Animasi 3 Dimensi. Karmapati.

[4] Saraswati Et Al. (2018). Pengaruh Penggunaan Media Pembelajaran E-Learning Quipper School Terhadap Hasil Belajar Lintas Minat Biologi Pada Siswa Kelas X Bahasa Semester Genap Di Sma Negeri 1 Sawan Tahun Pelajaran 2017/2018. Karmapati.

[5] Sucipto. (2017). Meningkatan Pemahaman Cara Berwudhu Melalui Penerapan Metode Demonstrasi Dan Simulasi Di Sekolah Dasar . Jurnal Riset Dan Konseptual.

[6] Sugihartini, N. (2016). Strategi Pembelajaran Pendekatan Pembelajaran Inovatif Disertai Dengan Aplikasi Pembelajaran Bidang Teknologi Informasi Dan Komunikasi (Tik). Undiksha Press.

[7] Sugiyono. (2012). Statistika Untuk Penelitian. Bandung: Alfabeta.

[8] Sugiyono. (2014). Metode Penelitian Pendidikan (Pendekatan Kuantitatif, Kualitatif, Dan R\&D). Bandung: Cv Alfabeta.

[9] Susetyo, B. (2015). Prosedure Penyusunan Dan Analisis Tes. Bandung: Pt Refika Aditama. 